ISSN No. 0974-035X

An Indexed, Refereed \& Peer Reviewed Journal of Higher Education

Towards Excellence

UGC-HUMAN RESOURCE DEVELOPMENT CENTRE,

GUJARAT UNIVERSITY, AHMEDABAD, INDIA

\title{
ISOLATION OF CHILDREN IN FOREIGN ABODES DUE TO CROSS BORDER BROKEN MARRIAGES
}

\section{Dr. Archana Shah}

\begin{abstract}
The world has become a global village and distance is no more the challenge. The direct impact of this positive change can be seen in interaction of various citizens of different countries belonging to diverse social, cultural and religious background. But cross border movements, inter-country migration and cross border marriages creates a new challenge like inter parental child abduction. In case of cross border broken marriages, there arise various issues like infringement of spouse's parental rights, parallel conflicting legal disputes in different countries, non participation of various countries to Hague convention for welfare of children, isolation of child in foreign abodes due to connection with Indian soil, etc.

Inter parental child abduction is neither considered as an offence, nor it is covered under any statutory laws of India. Like 94 nations, India is not a signatory to The Hague Convention on Civil Aspects of International Child Abduction, 1980, a multi lateral treaty developed by Hague Conference on Private International Law. Due to its non signatory status the judges of foreign countries do not trust Indian courts and do not permit the parent to take child to India, fearing its non-return.

In absence of any international legal instrument, the litigating parents will have to bear unnecessary expenses of visa, travel, litigation, etc and unfortunate child will become a trophy to be won in the clashes of egos of litigating parents.
\end{abstract}

Keywords: Hague Convention, child rights, inter parental child abduction. 
Towards Excellence: An Indexed, Refereed \& Peer Reviewed Journal of Higher Education / Dr.Archna Shah / Page 203-208

"Every child comes with a message that God is not yet discouraged of man"-

Rabindranath Tagore

The world has become a global village and distance is no more a challenge for human race. As a result of this positive change we find that citizens of various countries have started interacting with one another in spite of varied social, cultural and religious background. Being attracted to glitz and glamour of the western world, the craze among Indians marrying and studying abroad and giving birth to children to claim foreign citizenship has increased. But this increasing trend of cross border marriages and inter country migration has led to a new set of challenges for mothers and children. Diversity of backgrounds and inability to accept changed lifestyle often leads to matrimonial discord. In case of broken cross border marriages, there arise various issues like infringement of parental rights, parallel litigation in different countries dispute of child custody, etc. This tedious legal battle would result into unfortunate child being considered as a trophy to be won by litigating parents. It adversely affects the tender mind of isolated child, who generally develops ill will for the parent who is deprived of custody.

The Hague Convention on Civil Aspects of International Child Abduction is a multi lateral treaty developed by the Hague Conference on Private International Law in 1983, which provides for protection of children from harmful effects of abduction and a speedy return of a child internationally abducted by parent from one member country to another. The said Convention was designed to ensure prompt return of child who has been abducted from the country of habitual residence or wrongfully retained in contracting state. Here the main intention is to preserve whatever status quo child custody arrangement existed immediately before an alleged wrongful removal, thereby deterring a parent from crossing international boundaries in search of more sympathetic court. The Convention applies only to children under the age of 16 years. ${ }^{1}$

More than 90 countries have become signatory to the said Convention and have promised to hand over child back to the country of habitual residence, once the request is made by member nation. India has refused to become signatory to the said Convention. Moreover India does not recognize such abduction as an offence under any statutory law. In the recent case of 2016, Punjab and Haryana High court has forwarded a reference to Law Commission and Union Ministry of Women and Child Development for examining multiple issues involved in inter

\footnotetext{
${ }^{1}$ https://en.wikipedia.org/wiki/Hague_Convention_on_the_Civil_Aspects_of_International_Child_Abduction
} 
parental child removal issues ${ }^{2}$. The High Court also insisted on enacting a suitable law on the subject and for signing Hague Convention. In the said case, the minor without anyone's knowledge was taken to UK on fake passport, even after the court's order allowing petitioner to retain custody of child. The court then transferred the investigation to CBI. The child was later found in UK by British police who placed it in foster care. Before the London High Court could return the child to India, the child is missing and even police could not trace it. In this case the court observed that amicus curie Mr. Anil Malhotra ${ }^{3}$ has strongly suggested that India should accede towards signing of Hague Convention and enacting a domestic law in respect to inter country child removal, otherwise children will continue to be spirited away, from and to India.

\section{Landmark judgments relating to child abduction:}

- In the case of Ruchi Majoo v. Sajeev Majoo ${ }^{4}$, the Supreme Court clearly identifies the extra ordinary jurisdiction of writ court to examine the matter independently, whilst limiting the jurisdiction of Guardian judge if the removed child is not 'ordinary resident' in his territorial limits, provides the courts to follow the law of land.

- In the case of Roxann Sharma v. Aruna Sharma ${ }^{5}$, the Apex Court observed that the child is not a chattel or a ball that is bounced to and fro the parents. It is only child's welfare which is focal point of consideration. Parliament rightly thinks that the custody of child less than five years of age should ordinarily be with the mother and this expectation can be deviated from only for strong reasons.

- In the case of Surya Vandan v. State of Tamilnadu 6 , the Supreme Court directs the return of two girl children to UK in compliance with British court orders and lays down those salutary general principles to be followed as a mandate in child removal matters. The case was based on two principles 1) The principle of comity of courts 2) The principle of best interests and the welfare of child.

\footnotetext{
${ }^{2}$ Iqbal M., “Law Commission Receives Reference From High Court On Inter Parental Child Removal”. The Hindu. March 9, 2016.

${ }^{3}$ Anil Malhotra: a Chandigarh based lawyer who authored several books and practices in interpretation of foreign court orders regarding divorce decrees, child abduction, custody, etc.

${ }^{4}$ Ruchi Majoo v. Sanjeev Majoo . AIR 2011 SC 1952

${ }^{5}$ Roxann Sharma v. Aruna Sharma. (2015) 8 SCC 318.

${ }^{6}$ Surya Vandan v. State of Tamilnadu. JT 2015 (3) SC 85.
} 
Towards Excellence: An Indexed, Refereed \& Peer Reviewed Journal of Higher Education / Dr.Archna Shah / Page 203-208

In different cases High Courts and the Supreme Courts have considered child's interest and welfare to be paramount. The courts from case to case have tried to make positive interpretation of parental rights and have tried to carve out the solution.

\section{International position in respect to Hague Convention:}

The main purpose of the Convention is to facilitate signatory countries with reciprocal entitlements instead of having legal vacuum among them. Canada and Australia are the countries which need these provisions in acute as they are multi-racial and most favourable common destinations for migration. Of course all provisions of Convention are applicable to countries only when they have confirmed its operation both to its letter and spirit. In spite of being a signatory if they do not comply with Convention then reciprocity principle become meaningless. As far as African countries are concerned there is not much pressure imposed on them as they are embroiled in civil unrest. Moreover international child abduction cases are less. To impose pressure on Islamic countries for adopting this Convention would also be meaningless as they have different concepts of family law. In such countries, parental responsibilities are not equally shared between spouses. The governments of such countries would give priority to nationality and religion rather than any other issues.

\section{Should India become signatory to Hague Convention:}

Some proponents believe that India should become a signatory to Hague Convention, not just respecting the pressure from developed countries like UK and USA, but to respect gender equality. The kids who are born in foreign country are not the citizens of India and so should be returned to the country of habitual residence. Considering child's rights to be paramount, India must try to preserve the status quo of child arrangement which existed before abduction. India being a non-signatory has a negative influence on foreign judges as they fear that once the parent of broken marriage will take the child to India, will never return the child.

Some experts believe that India should not sign Hague Convention as signing would be unnecessary bowing down to foreign pressure. The Law Commission also opposes on the ground of term 'abduction' being used for child custody in broken marriages. The Commission argues that how can a parent abduct their own child. In many cases Indian women have got divorce from abusive and alcoholic NRI husbands and have also sacrificed their alimony for child's safety. Women of Indian origin if have come back to India after broken marriage will have to go 
back with child to foreign land and fight the lonely battle with no support, if India is a signatory. Moreover under Hague Convention, the burden of proof is on abducting parent to provide convincing evidence. In many cases NRI husbands have taken order from foreign courts to arrest the women the minute they enter the country.

\section{Conclusion:}

The proponents who urge India to sign Hague Convention fail to understand one simple fact that numbers of Indian children that are taken away from India to foreign countries are less. In comparison to that numbers of children who are brought into in to India, by either parent (mostly mother) are more. The mothers bring children to India considering their safety. Thus signing Hague Convention would mean bowing down to foreign pressure and accepting foreign interpretation of law, which is contrary to the law interpreted in India. 
Towards Excellence: An Indexed, Refereed \& Peer Reviewed Journal of Higher Education /

Dr.Archna Shah / Page 203-208

\section{$\underline{\text { References: }}$}

1. Iqbal, M. (2016, March 9) Law Commission Receives Reference from HC on Interparental Child Removal. The Hindu

http://www.thehindu.com/news/cities/Delhi/law-commission-receives-reference-from-hcon-interparental-child-removal/article8329312.ece

2. Jaising, I. (2017, January 30) It Would be Disastrous to Sign the Hague Convention on Child Abduction. The Hindustan Times

http://www.hindustantimes.com/opinion/it-would-be-disastrous-for-india-to-sign-thehague-convention-on-child-abduction/story-EG5vCj5FFbtjAbrtCxII5M.html

3. Lal, N. (2017, January 10) India's International Child Abduction Dilemma. The Diplomat.

https://thediplomat.com/2017/01/indias-international-child-abduction-dilemma/

4. Malhotra, A \& Malhotra R.(2016). India, Inter Country Parental Child Removal and the Law. Haryana: Universal Law Publishing.

5. Nair, S. (2016, November 27) India Will not Ink Hague Treaty on Civil Aspects of Child Abduction. The Indian Express

http://indianexpress.com/article/india/india-news-india/india-will-not-ink-hague-treatyon-civil-aspects-of-child-abduction-4397236/

6. PTI. (2017, October 5) India Must Sign Hague Convention on International Child Abduction: US. The Indian Express

http://www.newindianexpress.com/world/2017/oct/05/india-must-sign-hague-conventionon-international-child-abduction-us-1667146.html

7. Sengupta, A. (2016, August 18) Mothers in Hague Plea: Call to Govt not to Sign Child Abduction Convention. The Telegraph.

https://www.telegraphindia.com/1160818/jsp/nation/story_103093.jsp

\section{Dr. Archana Shah Assistant Professor, Somlalit Institute of Business Administration, Ahmedabad archanaumang@yahoo.com}

